\title{
Front Matter: Volume 8650
}

, "Front Matter: Volume 8650," Proc. SPIE 8650, Three-Dimensional Image Processing (3DIP) and Applications 2013, 865001 (28 March 2013); doi: $10.1117 / 12.2025758$

SPIE Event: IS\&T/SPIE Electronic Imaging, 2013, Burlingame, California, United SPIE. States 
PROCEEDINGS

IS\&T / SPIE

Electronic

Imaging

SCIENCE AND TECHNOLOGY

\title{
Three-Dimensional Image Processing (3DIP) and Applications 2013
}

\author{
Atilla M. Baskurt \\ Robert Sitnik \\ Editors \\ 6-7 February 2013 \\ Burlingame, California, United States \\ Sponsored by \\ IS\&T-The Society for Imaging Science and Technology \\ SPIE \\ Cosponsored by \\ Qualcomm Inc. (United States) \\ Published by \\ IS\&T-The Society for Imaging Science and Technology \\ SPIE
}


The papers included in this volume were part of the technical conference cited on the cover and title page. Papers were selected and subject to review by the editors and conference program committee. Some conference presentations may not be available for publication. The papers published in these proceedings reflect the work and thoughts of the authors and are published herein as submitted. The publishers are not responsible for the validity of the information or for any outcomes resulting from reliance thereon.

Please use the following format to cite material from this book:

Author(s), "Title of Paper," in Three-Dimensional Image Processing (3DIP) and Applications 2013, edited by Atilla M. Baskurt, Robert Sitnik, Proceedings of SPIE-IS\&T Electronic Imaging, SPIE Vol. 8650. Article CID Number (2013)

ISSN: 0277-786X

ISBN: 9780819494238

Copublished by

SPIE

P.O. Box 10, Bellingham, Washington 98227-0010 USA

Telephone +1 3606763290 (Pacific Time) · Fax +1 3606471445

SPIE.org

and

IS\&T-The Society for Imaging Science and Technology

7003 Kilworth Lane, Springfield, Virginia, 22151 USA

Telephone +1 7036429090 (Eastern Time) · Fax +1 7036429094

imaging.org

Copyright (C) 2013, Society of Photo-Optical Instrumentation Engineers and The Society for Imaging Science and Technology.

Copying of material in this book for internal or personal use, or for the internal or personal use of specific clients, beyond the fair use provisions granted by the U.S. Copyright Law is authorized by the publishers subject to payment of copying fees. The Transactional Reporting Service base fee for this volume is $\$ 18.00$ per article (or portion thereof), which should be paid directly to the Copyright Clearance Center (CCC), 222 Rosewood Drive, Danvers, MA 01923. Payment may also be made electronically through CCC Online at copyright.com. Other copying for republication, resale, advertising or promotion, or any form of systematic or multiple reproduction of any material in this book is prohibited except with permission in writing from the publisher. The CCC fee code is 0277-786X/13/\$18.00.

Printed in the United States of America.

Paper Numbering: Proceedings of SPIE follow an e-First publication model, with papers published first online and then in print and on CD-ROM. Papers are published as they are submitted and meet publication criteria. A unique, consistent, permanent citation identifier (CID) number is assigned to each article at the time of the first publication. Utilization of CIDs allows articles to be fully citable as soon as they are published online, and connects the same identifier to all online, print, and electronic versions of the publication. SPIE uses a six-digit CID article numbering system in which:

- The first four digits correspond to the SPIE volume number.

- The last two digits indicate publication order within the volume using a Base 36 numbering

system employing both numerals and letters. These two-number sets start with 00, 01, 02, 03, 04, $05,06,07,08,09,0 A, 0 B \ldots 0$, followed by 10-1Z, 20-2Z, etc.

The CID Number appears on each page of the manuscript. The complete citation is used on the first page, and an abbreviated version on subsequent pages. Numbers in the index correspond to the last two digits of the six-digit CID Number. 


\section{Contents}

vii Conference Committee

\section{SESSION 1 3D DATA PREPROCESSING}

865003 Depth image post-processing method by diffusion [8650-2]

Y. Li, M. Sjöström, U. Jennehag, R. Olsson, Mid Sweden Univ. (Sweden)

865004 Beta-function B-spline smoothing on triangulations [8650-3]

L. T. Dechevsky, P. Zanaty, Narvik Univ. College (Norway)

SESSION 2 TIME-OF-FLIGHT DATA, DEPTH MAPS ANALYSIS

865005 Evaluation of efficient high quality depth upsampling methods for 3DTV [8650-4]

L. P. J. Vosters, Technische Univ. Eindhoven (Netherlands) and Axon Digital Design (Netherlands); C. Varekamp, TP Vision Netherlands (Netherlands); G. de Haan, Technische Univ. Eindhoven (Netherlands)

865006 Multiview ToF sensor fusion technique for high-quality depth map [8650-5]

D. Kim, J. Choi, K. Sohn, Yonsei Univ. (Korea, Republic of)

865007 Time-of-flight depth image enhancement using variable integration time [8650-6] S. K. Kim, O. Choi, B. Kang, J. D. Kim, C.-Y. Kim, Samsung Advanced Institute of Technology (Korea, Republic of)

865008 Pseudo-random modulation for multiple 3D time-of-flight camera operation [8650-7] D.-K. Min, Samsung Electronics Co., Ltd. (Korea, Republic of); I. Ovsiannikov, Samsung Semiconductor, Inc. (United States); Y. Noh, W. Kim, S. Jung, J. Lee, D. Shin, H. Jung, L. Kim, Samsung Electronics Co., Ltd. (Korea, Republic of); G. Waligorski, L. Shi, Samsung Semiconductor, Inc. (United States); Y. Park, C. Chung, Samsung Electronics Co., Ltd. (Korea, Republic of)

865009 Lossy contour-coding in segmentation-based intra-depth map coding [8650-8] J. Hanca, A. Munteanu, P. Schelkens, Vrije Univ. Brussel (Belgium)

\section{SESSION 3 3D DATA PROCESSING FOR SPECIFIC APPLICATIONS}

8650 OA Estimation of spreading fire geometrical characteristics using near infrared stereovision [8650-9]

L. Rossi, T. Toulouse, Lab. SPE, CNRS, Univ. of Corsica (France); M. Akhloufi, Ctr. of Robotics and Vision (Canada); A. Pieri, Y. Tison, Lab. SPE, CNRS, Univ. of Corsica (France)

8650 OB Uniform grid upsampling of 3D lidar point cloud data [8650-10]

P. Gurram, S. Hu, A. Chan, U.S. Army Research Lab. (United States) 
8650 OC Improvements on a MMI-based method for automatic texture mapping of 3D dense models [8650-11]

P. Ferrara, Univ. degli Studi di Firenze (Italy) and Istituto Nazionale di Ottica (Italy);

F. Uccheddu, Univ. degli Studi di Firenze (Italy); A. Pelagotti, Istituto Nazionale di Ottica (Italy)

SESSION 4 SCENE ANALYSIS: FROM 2D VIEWS TO 3D RECONSTRUCTION AND INTERPRETATION

8650 OD Analysis of weighting of normals for spherical harmonic cross-correlation [8650-12]

R. L. Larkins, M. J. Cree, A. A. Dorrington, The Univ. of Waikato (New Zealand)

$8650 \mathrm{OE} \quad$ Edge-aided virtual view rendering for multiview video plus depth [8650-13]

S. M. Muddala, M. Sjöström, R. Olsson, S. Tourancheau, Mid Sweden Univ. (Sweden)

\section{SESSION $5 \quad$ 3D IMAGING SYSTEMS}

8650 OG Novel calibration procedure for SVBRDF estimation of 3D objects using directional illumination and structured light projection [8650-17]

J. F. Krzesłowski, R. Sitnik, G. Maczkowski, Warsaw Univ. of Technology (Poland)

$8650 \mathrm{OH} \quad$ Wide range time-of-flight camera: design, analysis, and simulation [8650-18]

O. Choi, Samsung Advanced Institute of Technology (Korea, Republic of)

8650 Ol Efficient intensity-based camera pose estimation in presence of depth [8650-19] M. El Choubassi, American Univ. of Beirut (Lebanon); O. Nestares, Y. WU, I. Kozintsev, H. Haussecker, Intel Corp. (United States)

8650 0J Depth correction in ToF camera [8650-20]

B. Kang, K. Lee, J. D. K. Kim, C.-Y. Kim, Samsung Advanced Institute of Technology (Korea, Republic of)

8650 OK Karate moves recognition from skeletal motion [8650-21]

S. Bianco, F. Tisato, Univ. degli Studi di Milano-Bicocca (Italy)

$8650 \mathrm{OL}$ Analyzing the relevance of shape descriptors in automated recognition of facial gestures in 3D images [8650-22]

J. S. Rodriguez A., F. Prieto, Univ. Nacional de Colombia (Colombia)

8650 OM 3D segmentation of the true and false lumens on CT aortic dissection images [8650-23] N. Fetnaci, P. Łubniewski, Institut des Sciences de l'Image pour les Techniques, CNRS, Univ. d'Auvergne Clermont-Ferrand I (France); B. Miguel, Institut des Sciences de I'Image pour les Techniques, CNRS, Univ. d'Auvergne Clermont-Ferrand I (France) and CHU GabrielMontpied (France); C. Lohou, Institut des Sciences de l'Image pour les Techniques, CNRS, Univ. d'Auvergne Clermont-Ferrand I (France) 
8650 ON Adaptive quality assurance of the product development process of additive manufacturing with modern 3D data evaluation methods [8650-24]

J. Kroll, S. Botta, J. Breuninger, A. Verl, Fraunhofer-Institut für Produktionstechnik und Automatisierung (Germany)

865000 Quality assessment of adaptive 3D video streaming [8650-25]

S. Tavakoli, J. Gutiérrez, N. García, Univ. Politécnica de Madrid (Spain)

$8650 \mathrm{OP}$ Introducing the cut-out star target to evaluate the resolution performance of 3D structuredlight systems [8650-26]

T. Osborne, V. Ramachandra, K. Atanassov, S. Goma, Qualcomm Inc. (United States)

INTERACTIVE PAPER SESSION

$86500 Q \quad$ Discovering unexpected information using a building energy visualization tool [8650-31]

B. Lange, N. Rodriguez, W. Puech, Lab. d'Informatique de Robotique et de Microelectronique de Montpellier (France); X. Vasques, IBM Corp. (France)

8650 OR An efficient anaglyph stereo video compression pipeline [8650-32]

A. Solichah Ahmadiyah, National Taiwan Univ. of Science and Technology (Taiwan); G.-M. Su, Dolby Labs., Inc. (United States); K.-L. Hua, Y.-C. Lai, National Taiwan Univ. of Science and Technology (Taiwan)

8650 OS Passive stereoscopic panomorph system [8650-27] A.-S. Poulin-Girard, S. Thibault, COPL, Univ. Laval (Canada); D. Laurendeau, Univ. Laval (Canada)

8650 OT 3D/2D image registration by image transformation descriptors (ITDs) for thoracic aorta imaging [8650-33]

P. J. Łubniewski, Institut des Sciences de l'Image pour les Techniques, CNRS, Univ. d'Auvergne Clermont-Ferrand I (France) and Cardinal Stefan Wyszyński Univ. (Poland); L. Sarry, Institut des Sciences de l'Image pour les Techniques, CNRS, Univ. d'Auvergne Clermont-Ferrand I (France); B. Miguel, Institut des Sciences de I'Image pour les Techniques, CNRS, Univ. d'Auvergne Clermont-Ferrand I (France) and CHU GabrielMontpied (France); C. Lohou, Institut des Sciences de I'Image pour les Techniques, CNRS, Univ. d'Auvergne Clermont-Ferrand I (France)

8650 OU Stereo matching with partial information [8650-34]

Y. C. Sübakan, Ö. C. Gürol, Ç. Dikici, Boğaziçi Univ. (Turkey)

8650 OV Self-calibration of depth sensing systems based on structured-light 3D [8650-30] V. Ramachandra, J. Nash, K. Atanassov, S. Goma, Qualcomm Inc. (United States)

8650 OW 3D hand localization by low-cost webcams [8650-28]

C.-Y. Ko, C.-T. Li, C.-H. Chung, L.-G. Chen, National Taiwan Univ. (Taiwan) 
8650 OX 3D shape extraction of internal and external surfaces of glass objects [8650-29]

A. Bajard, O. Aubreton, F. Truchetet, Lab d'Electronique, Informatique et Image, CNRS, Univ. de Bourgogne (France)

8650 OY Smarter compositing with the Kinect [8650-14]

A. Karantza, R. L. Canosa, Rochester Institute of Technology (United States)

Author Index 


\title{
Conference Committee
}

\author{
Symposium Chair
}

Gaurav Sharma, University of Rochester (United States)

Symposium Cochair

Sergio R. Goma, Qualcomm Inc. (United States)

Conference Chairs

Atilla M. Baskurt, University of Lyon (France)

Robert Sitnik, Warsaw University of Technology (Poland)

Conference Program Committee

Mongi A. Abidi, The University of Tennessee (United States)

Hugues Benoit-Cattin, Institut National des Sciences Appliquées de Lyon (France)

Adrian G. Bors, The University of York (United Kingdom)

Saida Bouakaz, University of Lyon (France)

Mohamed Daoudi, TELECOM Lille 1 (France)

Eduardo da Silva, Universidade Federal do Rio de Janeiro (Brazil)

Jean-Luc E. Dugelay, EURECOM (France)

Florent Dupont, University of Lyon (France)

Afzal Godil, National Institute of Standards and Technology (United States)

Benoît M. Macq, Université Catholique de Louvain (Belgium)

Serge Miguet, University of Lyon (France)

Levent Onural, Bilkent University (Turkey)

Eric Paquet, National Research Council Canada (Canada)

Marc Pollefeys, The University of North Carolina at Chapel Hill (United States)

William Puech, Laboratoire d'Informatique de Robotique et de Microelectronique de Montpellier (France)

Bülent Sankur, Boğaziçi Üniv. (Turkey)

Peter Schelkens, Vrije Universiteit Brussel (Belgium)

Michela Spagnuolo, Consiglio Nazionale delle Ricerche (Italy)

Frédéric Truchetet, Université de Bourgogne (France)

Stefano Tubaro, Politecnico di Milano (Italy) 
Session Chairs

3D Data Preprocessing

Atilla M. Baskurt, University of Lyon (France)

Time-Of-Flight Data, Depth Maps Analysis

Frédéric Truchetet, Université de Bourgogne (France)

3D Data Processing for Specific Applications

Robert Sitnik, Warsaw University of Technology (Poland)

Scene Analysis: From 2D Views to 3D Reconstruction and Interpretation

William Puech, Laboratoire d'Informatique de Robotique et de Microelectronique de Montpellier (France)

3D Imaging Systems

Robert Sitnik, Warsaw University of Technology (Poland)

3D Analysis, Feature Extraction, Segmentation, and Pattern

Recognition

Frédéric Truchetet, Université de Bourgogne (France)

Quality Assessment

Robert Sitnik, Warsaw University of Technology (Poland) 